\title{
PENGARUH KONTRASEPSI SUNTIK DMPA TERHADAP KENAIKAN BERAT BADAN TIKUS BETINA GALUR WISTAR
}

\author{
Dwi Retna Prihati \\ Kementerian Kesehatan Politeknik Kesehatan Surakarta Jurusan Kebidanan
}

\begin{abstract}
DMPA Injectable Contraception, Body Weight. The purpose of this study to determine the effect of contraception DMPA injection to BB in female blood wistar strain female. The benefits of this study are expected to increase public knowledge about injectable contraception especially related to the side effects of weight gain. This type of research is an experimental laboratory. Research design Randomized pre-post test group with control, the sample size of 10 adult female mice Wistar strain divided into 2 groups. Data were analyzed by independent T test. Significant value of $p<0.05$. The result of this research is there is significant difference between control group and DMPA contraception treatment group $(p=0,008)$. In conclusion contraceptive DMPA affects body weight wistar female rat strain .
\end{abstract}

Keywords: DMPA Injectable Contraception, Body Weight

\begin{abstract}
Abstrak: Kontrasepsi Suntik, Beran Badan. Tujuan dari penelitian ini untuk mengetahui pengaruh kontrasepsi suntik DMPA terhadap BB dalam darah tikus betina galur wistar. Manfaat dari penelitian ini diharapkan dapat menambah pengetahuan masyarakat tentang kontrasepsi suntik khususnya yang berkaitan dengan efek samping kenaikan berat badan. Jenis penelitian adalah exsperimental laboratory. Rancangan penelitian Randomized pre-post test group with control, besar sampel sebanyak 10 ekor tikus betina dewasa galur Wistar terbagi dalam 2 kelompok. Data dianalisis dengan independent $T$ test. Nilai signifikan $\mathrm{p}<0,05$. Hasil penelitian yaitu ada perbedaan bermakna antara kelompok kontrol dengan kelompok perlakuan kontrasepsi suntik DMPA $(\mathrm{p}=0,008)$. Kesimpulannya kontrasepsi suntik DMPA mempengaruhi kenaikan berat badan
\end{abstract}

Kata Kunci: Kontrasepsi Suntik, Beran Badan

\section{PENDAHULUAN}

Indonesia adalah salah satu Negara yang memiliki jumlah penduduk yang tinggi no.5 di Asia. Jumlah penduduk Indonesia pada tahun 2010 adalah 237.641.326 jiwa (BPS,2010). Tingginya jumlah penduduk ini tidak diiringi peningkatan kualitas penduduk di Indonesia, sehingga diperlukan upaya penanganan melalui program keluarga berencana $(\mathrm{KB})$ dengan menggunakan berbagai metode kontrasepsi (Handayani S., 2010; Noviawati D., 2009). Keluarga berencana telah menjadi salah satu sejarah keberhasilan pada abad ke-20. Saat ini, hampir $60 \%$ pasangan usia reproduktif diseluruh dunia menggunakan kontrasepsi. Keluarga berencana merupakan upaya pelayanan kesehatan preventif yang paling dasar, pencegahan kematian dan kesakitan ibu (Saifuddin, 2006). 
Kontrasepsi merupakan suatu cara untuk mencegah terjadinya kehamilan yang bertujuan untuk menjarangkan kehamilan, merencanakan jumlah anak dan meningkatkan kesejahteraan keluarga agar dapat memberikan perhatian dan pendidikan yang maksimal pada anak. Kontrasepsi hormonal yang di gunakan untuk mencegah terjadi kehamilan dapat memiliki pengaruh positif maupun negatif terhadap berbagai organ tubuh wanita, baik organ genitalia maupun non genitalia (Baziad, 2002). Tahun 2006 dilaporkan sebanyak 12 jt/100 juta penduduk dunia menggunakan kontrasepsi hormonal (DMPA) (Wilopo SA, 2006)

Metode kontrasepsi yang populer dan memiliki akseptor paling banyak diantara kontrasepsi lainnya adalah kontrasepsi suntik. Survey BKKBN di provinsi Jateng tahun 2011 menyebutkna bahwa penggunaan metode kontrasepsi hormonal mencapai 914.544 jiwa dan suntik menempati posisi tertinggi yaitu 594,283 jiwa. (BKKBN Jateng, 2011). Jenis kontrasepsi suntik ada 2 macam yaitu kontrasepsi suntik yang diberikan sebulan sekali berisi kombinasi $25 \mathrm{mg}$ Depo Medroksiprogesteron Asetat dan 5 mg estradiol sipionat yang diberikan injeksi secara intramuscular (Cyclofem). Depo Medroksi Asetat (Depoprovera), mengandung $150 \mathrm{mg}$ DMPA, yang diberikan setiap 3 bulan dengan cara disuntik intramuscular. Berbagai sumber menyebutkan bahwa satu efek samping dari kontrasepsi suntik baik yang kombinasi maupun progestin menyebabkan kenaikan berat badan. Penambahan berat badan ini mengindikasikan suatu metabolisme yang kurang seimbang antara jumlah kalori yang masuk dan yang dikeluarkan oleh tubuh. Hal ini terkait dengan insulin, pankreas dan kadar gula dalam darah.

Kontrasepsi hormonal (suntik) merangsang pusat pengendali nafsu makan dihipotalamus, yang menyebabkan akseptor makan lebih banyak daripada biasanya. DMPA mempengaruhi metabolisme karbohidrat. Permasalahan tersebut dapat menjadikan kadar glukosa dalam darah secara kuantitas naik dan akhirnya menyebabkan berat badan meningkat (Hartanto H., 2002) Kontrasepsi hormonal (suntik) menyebabkan resistensi insulin ringan sehingga memperburuk toleransi glukosa. Enilestradiol mengurangi bersihan insulin (sensitifitas insulin menurun), sedangkan gestagen mempengaruhi pemakaian glukosa perifer. (Baziad A., 2002). Perubahan kenaikan berat badan ini dapat dipengaruhi oleh berbagai faktor seperti faktor hormonal yang terkandung dalam kontrasepsi suntik DMPA yaitu hormone progesterone. Progesteron yang akan mempermudah perubahan karbohidrat dan gula menjadi lemak, sehingga lemak subkutan bertambah. Faktor lain yang berperan penting dalam mempengaruhi berat badan adalah faktor genetik, faktor lingkungan, faktor psikis, faktor obatobatan, dan aktivitas fisik(Hartanto, 2010; Irianto, 2014; Prawirohardjo, 2014)

\section{METODE PENELITIAN}

Jenis penelitian ini adalah exsperimental laboratory. Objek penelitian adalah tikus betina dewasa galur Wistar yang diberi kontrasepsi suntik suntik progesteron (DMPA) selama 90 hari dengan cara suntik secara intramuscular. Rancangan penelitian yang digunakan adalah Randomized pre-post test group with control. Penelitian ini menggunakan populasi tikus betina 
dewasa galur Wistar. Besar sampel sebanyak 10 ekor terbagi dalam 2 kelompok dan masing-masing kelompok yaitu, kelompok kontrol sebanyak 5 ekor (diberi DMPA dengan dosis $9 \mathrm{mg}$ dalam larutan 0,54ml) untuk 90 hari disuntikkan sekali). BB diukur hari pertama dan hari ke 90. Pemeliharaan dan perlakuan dilakukan di LPPT IV UGM Jogyakarta.

\section{HASIL PENELITIAN}

\section{A. Hasil Penelitian}

1. Perbedaan Berat Badan pre-post Kelompok kontrol dengan kelompok perlakuan DMPA

\section{Tabel 1}

Perbedaan Berat Badan Pre-Post Kelompok Kontrol Dengan Kelompok Perlakuan DMPA

\begin{tabular}{lccccc}
\hline Kelompok & Mean & SD & Min & Max & p \\
\hline Kontrol & & & & & \\
Pre & 135.7 & 1.3 & 112.4 & 142.8 & 0.043 \\
Post & 192.9 & 3.1 & 144.2 & 230.5 & \\
Perlakuan & & & & & \\
Pre & 153.0 & 8.3 & 141.4 & 160.6 & 0.000 \\
Post & 257.5 & 1.9 & 237.2 & 278.3 & \\
\hline
\end{tabular}

Dari tabel 1 menunjukkan bahwa perbedaan berat badan pre-post kelompok perlakuan lebih signifikan $(\mathrm{p}=0.000)$ dibanding kelompok kontrol $(\mathrm{p}=0.043)$.

2. Perbedaan kenaikan Berat Badan Kelompok kontrol dengan kelompok perlakuan DMPA

\section{Tabel 2}

Perbedaan Kenaikan Berat Badan Kelompok Kontrol Dengan Kelompok Perlakuan DMPA

\begin{tabular}{llllll}
\hline Kelompok & Mean & SD & Min & Max & p \\
\hline Kontrol & 57.1 & 2.1 & 31.8 & 88.8 & 0.008 \\
Perlakuan & 109.3 & 2.6 & 76.9 & 141.4 & \\
\hline
\end{tabular}

Dari tabel 2 menunjukkan bahwa ada perbedaan kenaikan berat badan antara kelompok kontrol dan kelompok perlakuan dengan nilai $\mathrm{p}=0.008$

\section{PEMBAHASAN}

Pada penelitian ini jenis kontrasepsi yang digunakan adalah DMPA yang berisi hormon progesteron Waktu penelitian 3 bulan tanpa jeda di LPPT IV UGM.

Tabel 1 menunjukkan bahwa keduanya baik kelompok kontrol maupun kelompok perlakuan ada perbedaan bermakna Berat Badan pre dan post. Hal ini dikarenakan tikus mengalami pertumbuhan dari yang umurnya rata-rata 12 minggu bertumbuh dan berkembang menjadi tikus dewasa yang berumur 24 mg. Tentu saja proses ini membuat tubuh menyesuaikan dengan menaikkan berat badannya. Tabel 1 menunjukkan bahwa kelompok perlakuan signifikansinya lebih tinggi dibandingkan kelompok kontrol, hal ini selaras dengan Tabel 2 yang memperlihatkan adanya perbedaan kenaikan Berat Badan yang signifikan antara kelompok kontrol dan Kelompok perlakuan DMPA. Peningkatan berat badan ini karena kontrasepsi suntik DMPA mengandung hormon progesteron yang mengakibatkan:

1. Meningkatnya nafsu makan

Kontrasepsi suntik menyebabkan nafsu makan bertambah, hal ini terjadi akibat perangsangan pusat pengendali nafsu makan di hipotalamus oleh Depo Medroksiprogesteron Acetat (DMPA) (Irianto, 2014). DMPA merangsang pusat pengendali nafsu makan dihipotalamus, yang menyebabkan akseptor makan lebih banyak daripada biasanya. (Hartanto $\mathrm{H}$., 2002). Hormon progesteron menyebabkan nafsu makan bertambah dan menurunkan aktifitas (Depkes, 2007)

2. Resistensi insulin

Kontrasepsi hormonal menyebabkan resistensi insulin ringan sehingga memperburuk toleransi glukosa. 
Enilestradiol mengurangi bersihan insulin (sensitifitas insulin menurun) sedangkan gestagen mempengaruhi pemakaian glukosa perifer. (Baziad A., 2002). DMPA mempengaruhi metabolisme karbohidrat. Permasalahan tersebut dapat menjadikan kadar glukosa dalam darah secara kuantitas naik. (Hartanto H., 2002). Hormon progesteron mengandung hormon steroid anti insulin rendah yaitu menurunkan jumlah dan afinitas reseptor insulin terhadap glukosa dan meningkatkan jumlah kortisol bebas (Amelia, 2009). Apabila jumlah insulin menurun maka insulin tidak dapat bekerja secara optimal untuk memindahkan gula darah kedalam sel untuk diubah menjadi energi dan glikogen (Rahayu, 2015).

3. Menurunnya kadar leptin

Tingginya kadar progesteron mengakibatkan defisiensi estrogen sehingga leptin yang diproduksi jaringan adiposa mengalami penurunan akibatnya sinyal yang mengatur homeostatis energi baik secara sentral maupun perifer menjadi terganggu. Peran leptin salah satunya adalah menekan sinyal nafsu makan (Limanan, 2013).

\section{Stress}

Progesteron dapat membuat emosional tidak stabil maupun depresi, wanita yang sedang stress, marah, atau memiliki gangguan emosi akan cenderung makan lebih banyak/ sering (prawirohardjo,2012). Di setiap sisi hipothalamus tampak adanya suatu area hipothalamus yang besar, area ini terutama untuk mempengaruhi rasa lapar, haus, dan hasrat emosional (Guyton, 2008).

Hasil penelitian ini sesuai dengan teori Hartanto (2010) dan Prawirohardjo (2014) yang menyatakan bahwa pemakaian kontrasepsi suntik bulanan maupun tiga bulanan mempunyai efek samping utama yaitu perubahan berat badan. Peningkatan berat badan terjadi karena bertambahnya lemak tubuh dan bukan karena retensi cairan tubuh. Hal ini dikarenakan penggunaan Depo Progestin dalam jangka panjang akan berkorelasi positif dengan kadar estrogen yang menurun sehingga akan berpengaruh pada jumlah lemak tubuh. Berdasarkan teori Mansjoer (2010) dan Triawanti (2010) menyebutkan bahwa defisiensi estrogen dapat menurunkan jumlah leptin yang diproduksi oleh jaringan adiposa sehingga sinyal kenyang menjadi ditekan. Dengan adanya nafsu makan yang lebih banyak dari biasanya tubuh akan kelebihan zat-zat gizi. Kelebihan zat-zat gizi oleh hormon progesteron diubah menjadi lemak dan disimpan di bawah kulit. Perubahan berat badan ini akibat adanya penumpukan lemak yang berlebih hasil sintesa dari karbohidrat menjadi lemak. Hasil penelitian Setyarini (2013) menunjukkan bahwa semakin lama penggunaan DMPA semakin besar persentase akseptor yang memiliki kadar lemak dalam interval 30$35 \%$ dan $>35 \%$ dalam kategori mendekati tinggi dan tinggi. Hal ini didukung oleh teori Hartanto (2010) dan Suparyanto (2010) yang menyatakan bahwa hal tersebut disebabkan oleh kandungan progesteron saja yang menyebabkan kadar estrogen menjadi berkurang. Fungsi estrogen antagonis terhadap progesteron salah satunya terhadap metabolisme lemak. Estrogen berfungsi meningkatkan kadar HDL (High-Density Lipoprotein) dan alpha lipoprotein yaitu lemak yang dapat larut dalam air. Sedangkan, progesteron menurunkan kadar HDL dan meningkatkan LDL (Low-Density Lipoprotein). LDL bersifat tidak larut dalam air sehingga apabila asupan 
makanan yang mengandung banyak lemak terus dikonsumsi maka LDL akan banyak tersimpan dalam tubuh. Penumpukan simpanan lemak dalam tubuh menyebabkan peningkatan berat badan.

\section{KESIMPULAN DAN SARAN Kesimpulan}

1. Perbedaan bermakna Berat Badan antara pre dan post pada kelompok perlakuan DMPA lebih signifikan yaitu $\mathrm{p}=0.000$ dibandingkan kelompok kontrol yaitu $\mathrm{p}=0.043$

2. Ada perbedaan kenaikan (delta) Berat Badan yang signifikan antara kelompok kontrol dan kelompok perlakuan DMPA yaitu $\mathrm{p}=0.008$.

\section{SARAN}

1. Bagi Akseptor kontrasepsi suntik DMPA untuk lebih mencermati kenaikan BB nya agar dapat mengontrol pola makan dan jenis makanan yang dikonsumsi, hal ini supaya tetap berada pada kondisi sehat.

2. Bagi tenaga kesehatan perlu memberikan penyuluhan efek samping kontrasepsi hormonal dan lebih memotivasi akseptor untuk memilih kontrasepsi non hormonal.

\section{DAFTAR RUJUKAN}

Baziad Ali. (2002). Kontrasepsi Hormonal. Jakarta. Yayasan Bina Pustaka

BKKBN. (2011). Informasi Pelayanan Kontrasepsi. Internet: http//www.bkkbn.com

BKKBN. (2015). Situasi dan Analisis Keluarga Berencana. Jakarta: Kementerian Kesehatan RI Pusat Data dan Informasi
BPS.(2010). Penduduk Indonesia

Provinsi. . Internet:

http//www.bps.go.id

Girindra, A.(1989). Biokimia

Patologi. Bogor : ITB

Guyton, AC., dan Hall,JE.(2008).

Buku ajar fisiologi kedokteran

edisi 11. Jakarta:EGC

Depkes RI. (2017). Pedoman

Penanggulangan Efek Samping

Kontrasepsi. Jakarta:Depkes RI

Handayani, Sri. (2010). Buku Ajar Pelayanan Keluarga Berencana. Yogyakarta. Pustaka Rihama

Hartanto, Hanafi. (2010). KB dan Kontrasepsi. Jakarta: Pustaka Sinar Harapan

Noviawati SA Dyah dan Sujiatini. 2009. Panduan Lengkap Pelayanan KB Terkini. Jogjakarta: Mitra Cendikia

Wilopo SA. 2006. Perkembangan Teknologi Kontrasepsi Terkini : Implikasinya pada program KB dan Kesehatan Reproduksi di Indonesia. FK UGM Yogyakarta 